\title{
Formation of a portfolio of innovation projects based on management of their life cycle parameters
}

\author{
Margarita Aleksandrova*, ${ }^{*}$, Nadezhda Sergeeva ${ }^{2}$, Lidiya $_{\text {Zakharova }}{ }^{3}$, Ella $_{\text {Okolelova }}{ }^{4}$ and \\ Marina Shibaeva ${ }^{4}$ \\ ${ }^{1}$ Moscow state University of technology and management K.G. Razumovsky, Zemlyanoy Val street, \\ 73, Moscow, 109004, Russia \\ ${ }^{2}$ Russian State University of Justice, 69, Novocheremushkinskaya street, 117418, Moscow, Russia \\ ${ }^{3}$ Moscow State University of Civil Engineering, Yaroslavskoye shosse, 26, Moscow, 129337, Russia \\ ${ }^{4}$ Voronezh State Technical University, Moscow Avenue, 14, Voronezh, 394026, Russia
}

\begin{abstract}
This paper presents the results of study of the analysis of the formation of a portfolio of innovation projects based on the management of their life cycle parameters. An algorithm for forming an innovation portfolio is proposed, which includes analysis of the duration of the life cycle stages and determining the level of competitiveness of the planned innovations in the portfolio, assessing risks, and forecasting the expected economic results when implementing them. An algorithm has been developed that allows choosing the optimal set of risk management methods as a part of an innovation project, which includes identifying factors that increase and decrease the impact of a particular risk on the innovation implementation process. The proposed methods of monitoring the competitiveness of innovation projects allow assessing the competitive possibilities of an innovation project, which allows determination of the main directions for its implementation.
\end{abstract}

\section{Introduction}

The life cycle of innovation is a certain period of time during which the innovation has activity and brings profit or other real benefit to the manufacturer or seller. The life cycle of an innovation project is a set of interrelated processes and stages of novelty. An innovation project generally has the following life cycle basis with clearly defined stages: development of innovation, preparation of production, entering the market, growth, maturity, recovery or decline. To maintain the competitiveness of an innovation project at all its stages, it is necessary to develop and implement innovations that are diverse in content and level of research intensity of innovations which are in the portfolio of the innovation project and implemented in a certain sequence.

\footnotetext{
* Corresponding author: maleksandrova@mail.ru
} 


\section{Materials and methods}

In the innovation project, first and second-order innovations are initially proposed for implementation. Innovations of the third and fourth order should dominate when the life cycle of product innovations will go down. As can be seen from Figure 1, at the stage of "maturity", the potential for growth of innovations is almost exhausted. At that moment, it is necessary to switch to the next group of innovations (Table 1), which ensures the extension of the stages of the innovation process $[1,2]$.

Table 1. Classification of innovations by the depth of the changes introduced by scientific research.

\begin{tabular}{|c|c|c|c|}
\hline $\begin{array}{c}\text { Type of } \\
\text { innovations }\end{array}$ & & $\begin{array}{l}\text { Types of innovations by the } \\
\text { level of research intensity }\end{array}$ & $\begin{array}{l}\text { Characteristics of the type } \\
\text { of innovations }\end{array}$ \\
\hline \multirow[b]{2}{*}{$\begin{array}{l}\text { Product } \\
\text { innovations }\end{array}$} & First order & $\begin{array}{l}\text { Radical innovations } \\
\text { (associated with the } \\
\text { introduction of small and } \\
\text { medium-sized inventions) }\end{array}$ & \multirow{2}{*}{$\begin{array}{l}\text { Introduction of new } \\
\text { products, diversification of } \\
\text { production towards high- } \\
\text { tech fast-growing segments } \\
\text { of the market, maintenance } \\
\text { of an active patent and } \\
\text { licensing policy. }\end{array}$} \\
\hline & Second order & $\begin{array}{l}\text { Improving innovations (aimed } \\
\text { at the survival of the firm, } \\
\text { appear as a reaction to radical } \\
\text { innovative transformations } \\
\text { carried out by competitors) }\end{array}$ & \\
\hline \multirow{2}{*}{$\begin{array}{l}\text { Technological } \\
\text { innovations }\end{array}$} & Third order & $\begin{array}{l}\text { Reactive innovations } \\
\text { (acquisition or development of } \\
\text { new technologies in order to } \\
\text { prevent further technological } \\
\text { lag from competitors) }\end{array}$ & \multirow{2}{*}{$\begin{array}{l}\text { Upgrade of equipment, } \\
\text { purchase of finished } \\
\text { technological lines and } \\
\text { technologies, localization or } \\
\text { introduction of third-party } \\
\text { technologies, introduction } \\
\text { of computer-aided design. }\end{array}$} \\
\hline & Fourth order & $\begin{array}{l}\text { Partial innovation (aimed at } \\
\text { partial improvement of } \\
\text { existing equipment and } \\
\text { technologies) }\end{array}$ & \\
\hline \multirow{2}{*}{$\begin{array}{l}\text { Organizational } \\
\text { and } \\
\text { managerial } \\
\text { innovations }\end{array}$} & Fifth order & $\begin{array}{l}\text { Basic innovations } \\
\text { (implement large inventions } \\
\text { and are the basis for the } \\
\text { formation of new generations } \\
\text { and directions for creating } \\
\text { products) }\end{array}$ & \multirow{2}{*}{$\begin{array}{l}\text { Innovations introduced into } \\
\text { the processes of interaction } \\
\text { of the enterprise with the } \\
\text { external environment, in the } \\
\text { management of the flow of } \\
\text { material resources and } \\
\text { money. Structuring of } \\
\text { relations between } \\
\text { departments, strengthening } \\
\text { the role of planning and } \\
\text { budgeting, personnel } \\
\text { rotation, computerization of } \\
\text { management information } \\
\text { processing. }\end{array}$} \\
\hline & Sixth order & $\begin{array}{l}\text { Strategic } \\
\text { (proactive and aimed at } \\
\text { obtaining } \\
\text { competitive advantages in the } \\
\text { future) }\end{array}$ & \\
\hline
\end{tabular}

The analysis of the duration of the stages of the innovation life cycle is based on the assessment of technical and economic indicators (Table 2). The results of the assessment make it possible to determine the maximum period of effectiveness of implemented innovation developments, contribute to the formation of an innovation portfolio and the development of a competitive innovation project [3]. 


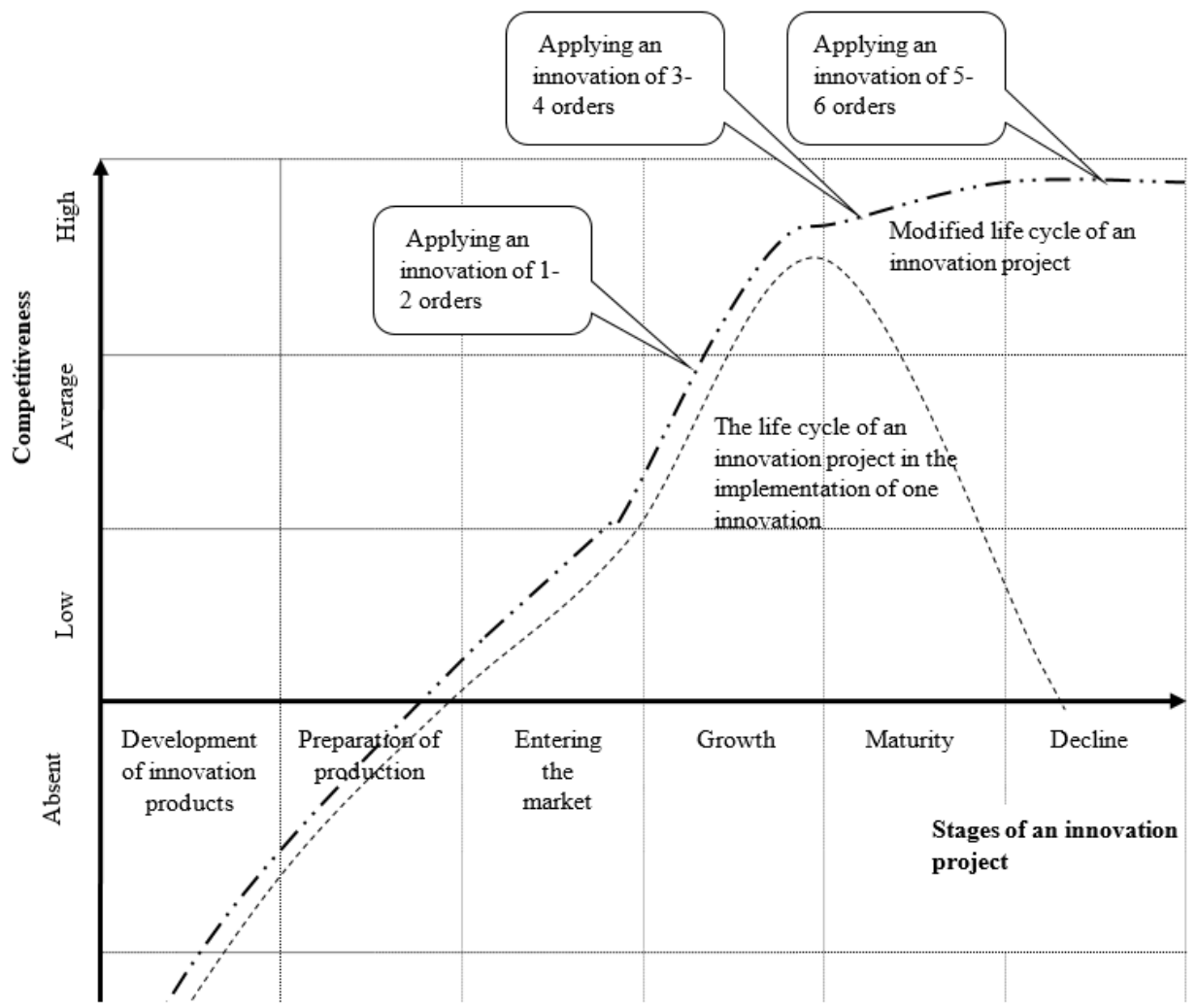

Fig. 1. Interrelation of the competitiveness of an innovation project and the life cycle of innovation.

Table 2. Analysis of the stages of the innovation life cycle.

\begin{tabular}{|c|c|c|}
\hline $\begin{array}{c}\text { Type of } \\
\text { innovations }\end{array}$ & $\begin{array}{l}\text { Values of technical and economic } \\
\text { indicators }\end{array}$ & Stage of life cycle \\
\hline \multirow{3}{*}{$\begin{array}{l}\text { Product } \\
\text { innovations }\end{array}$} & $\begin{array}{l}\mathrm{C}_{\mathrm{IP}} \in(75 ;+\infty) ; \mathrm{D}_{\mathrm{FA}} \in(0 ; 32) ; \\
\mathrm{PS}_{\mathrm{S}} \in(35 ;+\infty) ; \mathrm{P}_{\mathrm{I}} \in(68 ;+\infty)\end{array}$ & Growth \\
\hline & $\begin{array}{l}\mathrm{C}_{\mathrm{IP}} \in[28 ; 75] ; \mathrm{D}_{\mathrm{FA}} \in[32 ; 80] \\
\mathrm{PS} \in[8 ; 35] ; \mathrm{PI} \in[25 ; 68]\end{array}$ & Maturity \\
\hline & $\begin{array}{l}\mathrm{C}_{\mathrm{IP}} \in(0 ; 28) ; \mathrm{D}_{\mathrm{FA}} \in(80 ;+\infty) \\
\mathrm{P}_{\mathrm{S}} \in(0 ; 8) ; \mathrm{P}_{\mathrm{I}} \in(0 ; 25)\end{array}$ & $\begin{array}{l}\text { Decline. A transition to the } \\
\text { "Recovery" stage and the } \\
\text { implementation of technological } \\
\text { innovations are needed }\end{array}$ \\
\hline \multirow{3}{*}{$\begin{array}{l}\text { Technological } \\
\text { innovations }\end{array}$} & $\begin{array}{l}\text { D IT }_{\text {IT }}(0 ; 15) ; \mathrm{C}_{\mathrm{ME}} \in(0 ; 39) ; \\
\mathrm{P}_{\mathrm{S}} \in(35 ;+\infty) ; \mathrm{P}_{\mathrm{I}} \in(68 ;+\infty)\end{array}$ & Growth \\
\hline & $\begin{array}{l}\text { DIт } \in(47 ;+\infty) ; C_{M E} \in[39 ; 64] ; \\
P_{S} \in[8 ; 35] ; P_{I} \in[25 ; 68]\end{array}$ & Maturity \\
\hline & $\begin{array}{l}\mathrm{D}_{\mathrm{IT}} \in[15 ; 47] ; \mathrm{C}_{\mathrm{ME}} \in(64 ;+\infty) \\
\mathrm{P}_{\mathrm{S}} \in(0 ; 8) ; \mathrm{P}_{\mathrm{I}} \in(0 ; 25)\end{array}$ & $\begin{array}{l}\text { Decline. A transition to the } \\
\text { "Recovery" stage and } \\
\text { implementation of organizational } \\
\text { and managerial innovations are } \\
\text { needed }\end{array}$ \\
\hline
\end{tabular}




\begin{tabular}{|c|c|c|}
\hline \multirow{3}{*}{$\begin{array}{l}\text { Organizational } \\
\text { and managerial } \\
\text { innovations }\end{array}$} & $\begin{array}{l}\text { CPE }_{\mathrm{P}}(0 ; 17) ; \text { ЕHE } \in(0 ; 23) ; \\
\mathrm{PSS}_{\mathrm{S}} \in(35 ;+\infty) ; \mathrm{PI} \in(68 ;+\infty)\end{array}$ & Growth \\
\hline & $\begin{array}{l}\mathrm{C}_{\mathrm{PE}} \in[17 ; 34] ; \mathrm{E}_{\mathrm{HE}} \in[23 ; 51] ; \\
\mathrm{P}_{\mathrm{S}} \in[8 ; 35] ; \mathrm{P}_{\mathrm{I}} \in[25 ; 68]\end{array}$ & Maturity \\
\hline & $\begin{array}{l}\mathrm{CPE}_{\mathrm{PE}} \in(34 ;+\infty) ; \mathrm{E}_{\mathrm{HE}} \in(51 ;+\infty) \\
\mathrm{PS}_{\mathrm{S}} \in(0 ; 8) ; \mathrm{PI}_{\mathrm{I}} \in(0 ; 25)\end{array}$ & Decline \\
\hline \multicolumn{3}{|c|}{$\begin{array}{l}\text { Explanation of symbols: } \mathrm{D}_{\mathrm{FA}}-\text { level of depreciation of fixed production assets; } \mathrm{C}_{\mathrm{IP}}-\text { specific } \\
\text { weight of innovation costs in the total output of product; PS - profitability of sales; } \mathrm{P}_{\mathrm{I}}- \\
\text { profitability of innovations; } \mathrm{C}_{\mathrm{ME}}-\text { specific weight of the cost of machinery and equipment in the } \\
\text { total amount of fixed assets; } \mathrm{D}_{\mathrm{IT}}-\text { level of development of new science-intensive technologies; } \\
\mathrm{C}_{\mathrm{PE}}-\text { share of costs for professional education in the total amount of labor costs; E E } \text { - share of } \\
\text { employees with higher education in the total number of industrial and production personnel. }\end{array}$} \\
\hline
\end{tabular}

\section{Results}

For the successful formation of the innovation project and its further implementation, there should be several options for innovation in stock, i.e. "portfolio" of innovative ideas. An algorithm for forming an innovation portfolio as a part of the innovation project (Figure 2) is proposed in the paper, which includes the following basic procedures $[4,5]$.

1. Analysis of the external environment and making a list of the most significant criteria the objectives of the innovation project.

2. Planning innovations in the portfolio with regard to their areas (product, technological, organizational and managerial).

3. Assessment of the level of competitiveness and life cycle for each planned innovation in the project portfolio.

4. Exclusion of innovations from the portfolio that do not meet the stated criteria. The remaining innovations form preliminary proposals on priority directions of portfolio formation.

5. Innovations that meet the stated criteria are assessed for the degree of risk, profitability and efficiency.

The assessment of the level of competitiveness of each planned innovation in the project portfolio includes the following stages.

1. Selection of the most competitive product (service, technology, management method) as a basis for comparing the competitiveness of innovation. The sample should belong to the same target market as the innovation, to be the most representative on it.

2. The parameters by which the innovation under consideration and the existing product are compared are presented in Table 3. The mathematical and statistical apparatus of expert evaluations was used to order the criteria. Expert analysis allowed obtaining weighting factors for determining the competitive position of innovation $[6,7]$. 


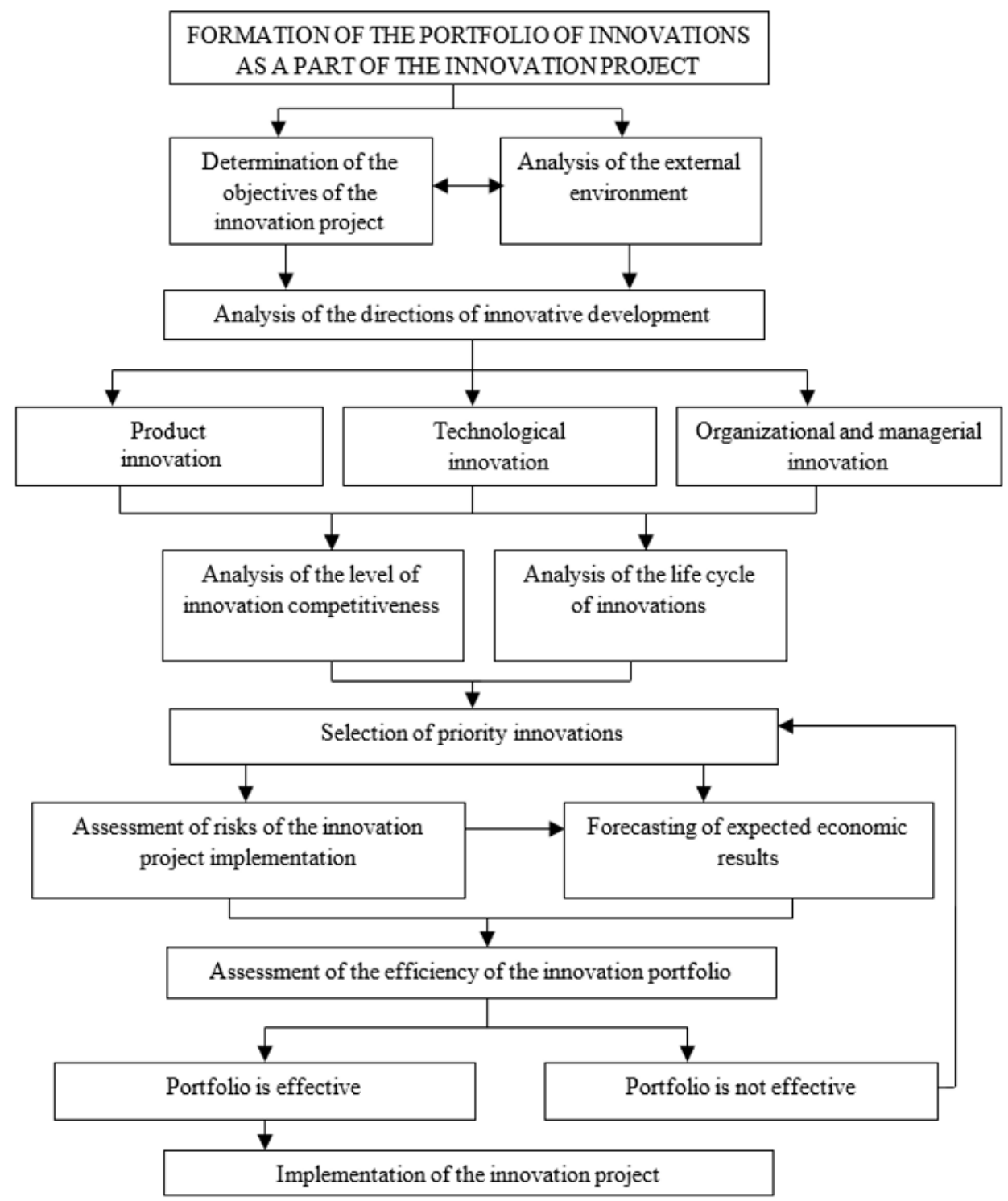

Fig. 2. Algorithm for the formation of the innovation portfolio as a part of the innovation project.

Table 3. Weighting factors of innovation competitiveness factors.

\begin{tabular}{|c|l|c|c|}
\hline No & Key factors & Weight of factor & Symbol \\
\hline 1. & Purpose of innovation & 0,09 & $\mathrm{~B}_{1}$ \\
\hline 2. & Duration of the innovation life cycle & 0,23 & $\mathrm{~B}_{2}$ \\
\hline 3. & Degree of risk of innovation & 0,12 & $\mathrm{~B}_{3}$ \\
\hline 4. & Level of innovation efficiency & 0,25 & $\mathrm{~B}_{4}$ \\
\hline 5. & Degree of feasibility of innovation & 0,14 & $\mathrm{~B}_{5}$ \\
\hline 6. & Degree of novelty of innovation & 0,17 & $\mathrm{~B}_{6}$ \\
\hline 7. & Total & 1,00 & \\
\hline
\end{tabular}


3. Assessment of innovation competitiveness according to the presented parameters is carried out according to the following formula:

$$
C_{I}=\sum_{i=1}^{6} F i i^{*} W i / R s i
$$

where $\mathrm{C}_{\mathrm{I}}-$ an indicator of innovative competitiveness according to the parameters presented in Table 4, i=1..6; $\mathrm{W}_{\mathrm{i}}$ - weight of $\mathrm{i}$-th factor, $\Sigma \mathrm{W}_{\mathrm{i}}=1 ; \mathrm{F}_{\mathrm{Ii}}$ - value of the i-th innovation factor (assessment in points from 1 to 5 ); $\mathrm{R}_{\mathrm{si}}$ - value of the $\mathrm{i}$-th factor of the competitor sample (assessment in points from 1 to 5). The values of the innovation competitiveness index are presented in Table 4.

Table 4. The level of competitiveness of innovation in the portfolio.

\begin{tabular}{|l|c|}
\hline \multicolumn{1}{|c|}{$\begin{array}{c}\text { Characteristics of innovation } \\
\text { competitiveness }\end{array}$} & $\begin{array}{c}\text { Interval of values of the level of innovation } \\
\text { competitiveness }\end{array}$ \\
\hline High level of competitiveness & $\mathrm{C}_{\mathrm{I}} \in(4 ; 5]$ \\
\hline Average level of competitiveness & $\mathrm{C}_{\mathrm{I}} \in(1,9 ; 4]$ \\
\hline Low level of competitiveness & $\mathrm{C}_{\mathrm{I}} \in(1 ; 1,9]$ \\
\hline Uncompetitive innovation & $\mathrm{C}_{\mathrm{I}} \in[0,2 ; 1]$ \\
\hline
\end{tabular}

A feature of innovation projects is that they are classified as high risk objects for investment. The author developed an algorithm for managing the risks of innovation projects (Figure 3).

Localization of risks in the implementation of the innovation project is achieved in the process of analyzing and modeling the portfolio of innovations. In order to choose the optimal set of risk management methods as a part of a specific innovation project, it is necessary to assess the set of a number of factors: the complexity (specificity) of innovation activity; level of profitability of innovations in a specified time interval; the cost of insurance services; probability, size and specificity of the risk; predictability of risk; restrictions and prescriptions of legislation; stage of project implementation [8,9].

The algorithm of risk management of innovation projects with a change in the duration of their life cycle includes a number of successive stages:

1) identification of factors that increase and reduce the impact of a particular risk on the innovations being implemented;

2) definition of a system of risk assessment indicators that depend on factors affecting the innovation project;

3) identification of potential risk areas, i.e. definition of innovative measures, operations, and works, in the performance of which there may be uncertainty in obtaining a positive result;

4) identification of all possible risks of the innovation project, including determination of possible risks as a result of changes in their life cycle [10]. 


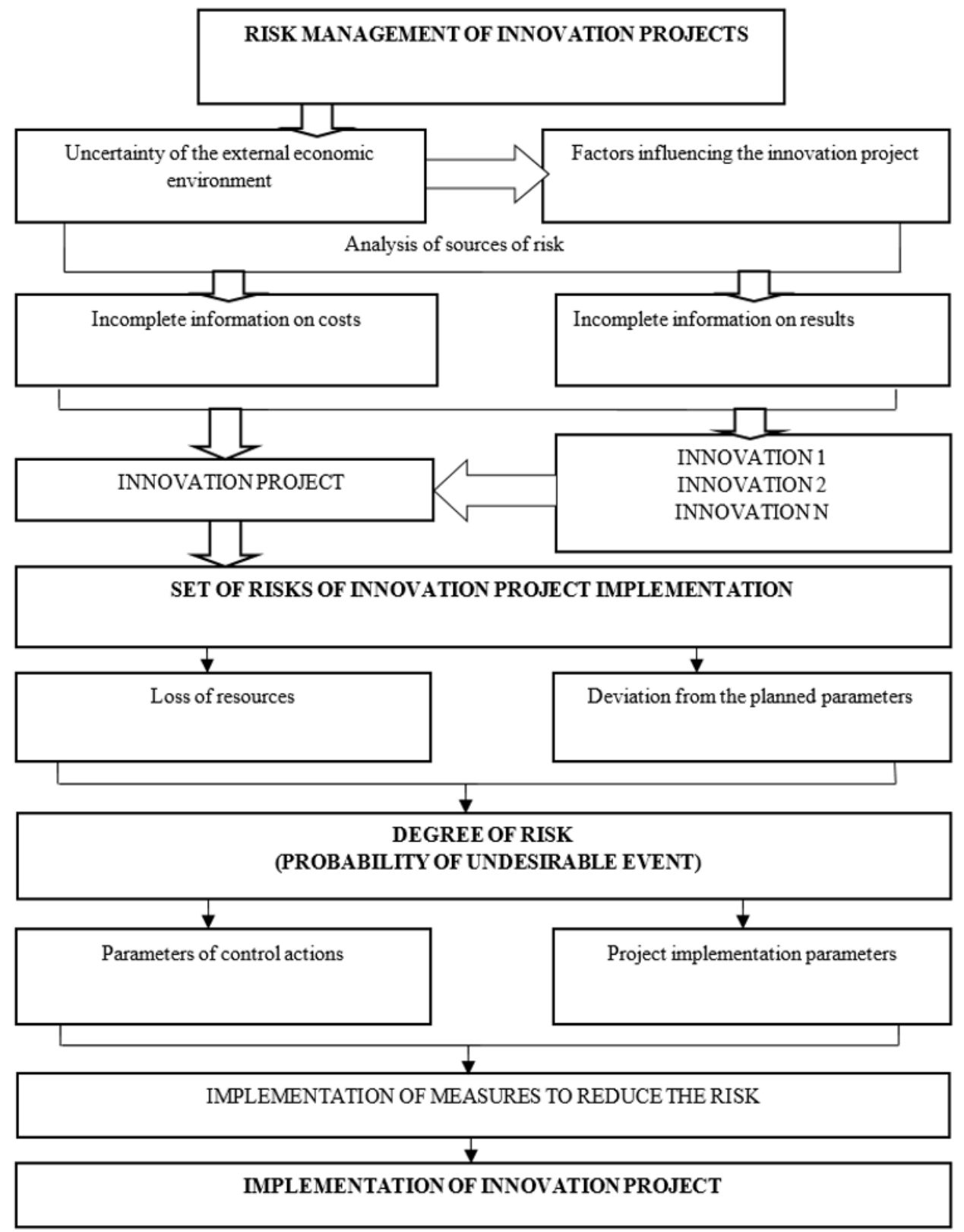

Fig. 3. Algorithm for risk management of innovation projects.

The study of the theory of monitoring research and the analysis of the competitiveness of innovation projects make it possible to formulate general methods for monitoring the competitiveness of the innovation project being implemented (Table 4). The main stage of monitoring research proposes to analyze the competitive position of the innovation project and its innovations [11]. 
Table 4. Directions for the implementation of innovation projects.

\begin{tabular}{|l|l|l|l|l|}
\hline \multirow{2}{*}{ Competitiveness } & \multicolumn{3}{|c|}{ Stage of the life cycle of the innovation project } \\
\cline { 2 - 5 } High & Entering the market & \multicolumn{1}{|c|}{ Growth } & \multicolumn{1}{c|}{ Maturity } & Decline \\
\hline \multirow{2}{*}{ Average } & $\begin{array}{l}\text { Investing faster than } \\
\text { market } \\
\text { requirements }\end{array}$ & $\begin{array}{l}\text { Retention of } \\
\text { position } \\
\text { Retention of } \\
\text { share }\end{array}$ & $\begin{array}{l}\text { Retention of } \\
\text { position } \\
\text { Development } \\
\text { together with } \\
\text { industry }\end{array}$ & $\begin{array}{l}\text { Retention of } \\
\text { position }\end{array}$ \\
\hline Low & $\begin{array}{l}\text { Increase in market } \\
\text { share }\end{array}$ & $\begin{array}{l}\text { Selective } \\
\text { increase in } \\
\text { market } \\
\text { share }\end{array}$ & $\begin{array}{l}\text { Waiting or } \\
\text { stabilizing } \\
\text { Finding of your } \\
\text { niche }\end{array}$ & $\begin{array}{l}\text { Summing up or } \\
\text { leaving the } \\
\text { market }\end{array}$ \\
\hline & $\begin{array}{l}\text { Selective approach } \\
\text { to winning } \\
\text { positions }\end{array}$ & $\begin{array}{l}\text { Finding of } \\
\text { your niche }\end{array}$ & $\begin{array}{l}\text { Finding of your } \\
\text { niche or leaving the } \\
\text { market }\end{array}$ & $\begin{array}{l}\text { Leaving the } \\
\text { market }\end{array}$ \\
\hline
\end{tabular}

In the generated matrix, each element (innovation) of the project takes its initial strategic position, which, through their subsequent correction, enables management to choose the direction of the innovation project development and significantly reduce the risk of innovations being introduced and aimed at obtaining the expected economic effect.

\section{Discussion}

On the basis of the above, the following monitoring methods are proposed, ensuring high competitiveness of the innovation project:

1. The method of complete research. In this case, when managing an innovation project, the analysis is carried out continuously, which helps maintain the overall portfolio costs at the same level, control profitability, risk, and also the degree of novelty of the portfolio. Studies are conducted simultaneously on innovations of different directions.

2. The method of rapid assessment. Analysis of available information on the competitiveness of innovations, including the study of the integral indicator and the definition of the life cycle of innovations implemented at the time of research.

3. The method of sequential assessment. It presupposes the analysis of the stage of the life cycle of the innovation portfolio, the determination of the initial strategic position, and the construction of the logic of decision-making about the innovations being introduced. The analysis includes an assessment of the profitability, risk and competitiveness indicators of both the individual innovation and the entire portfolio at each stage of the sequence adopted. In this case, high profitability of innovations and high risk are allowed.

4. The method of modern work. It assumes the analysis of the competitiveness of innovations implemented in the project, their life cycle and profitability. The peculiarity of this method is active involvement in the decision-making of those persons who take part in the implementation of the innovation project, for which reason the level of result awareness increases. In this case, there is a minimum degree of risk, combined with high reliability and elaboration of innovation projects.

\section{Conclusion}

The proposed solutions allow choosing the optimal set of risk management methods as a part of the innovation project. The developed methodology for monitoring the competitiveness of the risks of innovation projects, the main constructive element of which is the formation of a matrix of competitive possibilities of an innovation project, allows defining the main directions of their implementation. 


\section{References}

1. S.V. Belyaeva, Procedia Engineering 165, 1046-1051 (2016)

2. L. Grilli, M. Mazzucato, M. Meoli, G.Scellato, Technological Forecasting and Social Change 127, 1-7 (2018)

3. O.V. Papelnuk, Economics and Entrepreneurship 3-1(80-1), 1013-1016 (2017)

4. S. Borrás, Ch. Edquist, Technological Forecasting and Social Change 80-8, 1513-1522 (2013)

5. Z.I. Ivanova, O.V. Yudenkova, A.D. Ishkov, E.A. Shnyrenkov, International Education Studies 5, 232-239 (2015)

6. A.K. Orlov, MATEC Web of Conferences 106 (2017)

7. V. Kankhva, Procedia Engineering 165, 1300-1304 (2016) doi:10.1016/j.proeng.2016.11.855

8. B. Marchi, M. Pasetti, S. Zanoni. Enrgy Proced, 113 (2017), DOI: 10.1016/j.egypro.2017.04.034

9. N.E. Tihonova, Social'naya struktura Rossii: teorii i real'nost' (Novyj hronograf: In-t sociologii RAN, Moscow, 2014)

10. N. Safronova, E. Nezhnikova, A. Kolhidov, MATEC Web of Conferences (2017) https://doi.org/10.1051/matecconf/201710608024.

11. A. Larionov, MATEC Web of Conferences 106, 09022 (2017) 